\title{
Technological Gap in Adoption of Improved Paddy Cultivation Practices
}

\author{
M.B. Tengli ${ }^{*}$ and O.P. Sharma ${ }^{2}$ \\ ${ }^{1}$ Division of Dairy Extension, ICAR-NDRI, Karnal, 132001, Haryana, India \\ ${ }^{2}$ Department of Agricultural Extension, NMCA, NAU, Navsari, 396450, Gujarat, India \\ *Corresponding author
}

\begin{tabular}{|c|c|}
\hline & A B S T R A C T \\
\hline Keywords & \multirow{4}{*}{$\begin{array}{l}\text { The aforementioned study was conducted in Navsari and Surat districts of South Gujarat } \\
\text { during the year 2014-2016. The primary data was collected from } 100 \text { respondents by } \\
\text { personal interview method using structure interview schedule. After the analysis of the } \\
\text { data, it was observed that, majority of the paddy growers }(85.00 \%) \text { belonged to medium } \\
\text { level of overall technological gap category. } 75.00 \text { per cent gap was found in adoption of } \\
\text { recommended herbicide in transplanted field and least gap }(24.00 \%) \text { was found in case of } \\
\text { adoption of recommended variety. Socio-economic variables associated with the } \\
\text { respondents, such as risk orientation, scientific orientation, education, annual income and } \\
\text { mass media exposure, extension participation, extension contact and social participation } \\
\text { were negatively and significantly associated with the overall technological gap. The above } \\
\text { results compel the research and extension system to work on the gaps and negative } \\
\text { relationship in a pragmatic way. }\end{array}$} \\
\hline $\begin{array}{l}\text { Adoption, Cultivation } \\
\text { practices, Paddy, } \\
\text { South Gujarat, } \\
\text { Technological gap. }\end{array}$ & \\
\hline Article Info & \\
\hline $\begin{array}{l}\text { Accepted: } \\
\text { 12 September } 2017 \\
\text { Available Online: } \\
\text { 10 November } 2017\end{array}$ & \\
\hline
\end{tabular}

\section{Introduction}

Agriculture the engine of Indian social heritage and rural economy, having been aiding as a major source of rural employment and national food security. Rice (Oryza sativa L.) is considered as a first cultivated crop of Asia. India positions second with 154.6 million tonnes of paddy next to China (FAO, 2015). With the world population projected to about 8.2 billion in the year 2030, the global rice demand will rise to approximately 765 million tonnes (FAO, 2014). Since the Green Revolution, the rice yield growth rate has declined to 1.1 per cent (Riveros and Figures, 2000). As far as average yield per hectare is concerned, Korea Republic ranks first (5200 $\mathrm{kg} / \mathrm{ha}$ ) and that of India is only $2424 \mathrm{~kg} / \mathrm{ha}$ (Anonymous, 2014a). Rice, in addition being a major source of dietary energy, constitutes a natural medicine used mainly as a popular medication. The average yield in the districts under study Navsari \& Surat is $3600 \mathrm{~kg}$ per hectare \& $3650 \mathrm{~kg}$ per hectare, respectively. It is observed from the yield of paddy, the average yield at national level is $2424 \mathrm{~kg}$ per hectare and the average yield of rice of Gujarat state is 1500-1800 kg per hectare (Mehta et al., 2010). Similarly, Paddy yield instability is being reported and it can be reduced by more investment on research leading to evolving of suitable rice production technology for varied agro climatic conditions of the Gujarat state. It is because of the poor productivity of this fragile ecosystem that brings down the total productivity (Narendra 
et al., 2014). Some of the studies reported higher technological gap in case of winter rice in comparison to other cereals (Sharma, 2012). It is clear with the above background information that gap exist in adoption of the technology which negatively influences the production and productivity of the crop. Thus present study was undertaken. The outcome of the study is expected to contribute the extension personnel and policy planners in developing Strategic Research and Extension Plan (SREP) for the study area, and reduce the identified gaps in paddy production technology. With this premise the above study was undertaken with following specific objectives,

To know the technological gap in adoption of improved paddy cultivation practices

To ascertain the relationship between the technological gap and selected independent variables

\section{Materials and Methods}

The Ex-post-facto-research design was applied for this study and Navsari and Surat districts of South Gujarat region was locale of the study. There are seven districts in South Gujarat region out of those Navsari (3600 $\mathrm{kg} / \mathrm{ha}$ ), (Anonymous, 2014b) and Surat district (3650 kg/ha) (Anonymous, 2014c) were selected purposely as they are having highest productivity of paddy among all the seven districts. Form each selected district one taluka was selected following simple random sampling. Likewise from each selected taluka five villages were selected. In this way, total ten villages were selected for this study; from each village ten respondents (paddy growers) were selected randomly. A total of 100 respondents were interviewed for data collection. Personal interview method was followed to seek information, using structured interview schedule. Technological gap had been conceived as the difference between the packages of practices of paddy cultivation recommended by of Navsari Agricultural University and the extent of adoption of selected recommended practice at farmer's field level.Under each of the selected major practices, sub-practices were identified. The Gap for each major practice was calculated by deducting the number of sub practices adopted by the respondents from the total number of sub-practices adopted by the respondents. The per cent technological gap for each major practice and for the whole package, were worked out with help of following formula

Technological gap $=\frac{\text { No. recommended practices }- \text { No. adopted practices }}{N o . r e c o m m e n d e d ~ p r a c t i c e s ~}$ No. recommended practice

Mean technological gap $=\frac{\text { Total gap for all practices considered }}{\text { No. practices considered }} \times 100$

Technolog ical gap $=\frac{\mathbf{S}-\mathbf{A}}{\mathbf{A}} \times 100$

Here $S=$ Standard score (Total number of respondents), $\mathrm{A}=$ Actual score.

On the basis of overall technological gap, the respondents were grouped into three categories considering the mean and standard deviation as measure of check.Correlation between overall technological gap and selected independent variables was computed. The data was analyzed and results were interpreted accordingly.

\section{Results and Discussion}

\section{Socio-economic profile of the respondents}

Socio-economic status of the respondents is an important and integral part of any social science research. The profile study reveals that, half of the respondents $(50.00 \%)$ belonged to middle age category, majority of the respondents $(58.00 \%)$ had education up to the secondary level of education, 90.00 
percent respondents were having medium (6 to 15 years) to high level (Above 15 years) of farming experience, 54.00 percent of them had medium ( 2 to 5 Acres) land holding, with 61.00 percent belonging to low income category (Rs. 50,001/- to 1,00,000/-), more than 70.00 percent respondents belonged to medium categories in following variables, material possession $(70.00 \%)$, mass media exposure $(73.00 \%)$, risk orientation $(80.00$ $\%)$, social participation $(77.00 \%) .55 .00$ percent, 53.00 percent and 44.00 percent of respondents belonged to medium categories of scientific orientation, extension contact and extension participation, respectively.

\section{Extent of technological gap in adoption of improved paddy cultivation practices}

\section{Overall technological gap in adoption of improved paddy cultivation practices}

The data presented in the table 1 , revealed that majority of the respondent paddy growers $(85.00 \%)$ belonged to medium overall technological gap category with mean technological gap score of 56.51, followed by 15.00 per cent of respondent who belong to low overall technological gap categories with mean technological gap score of 21.94.

It is also evident from the data presented in the same table that not a single respondent paddy grower belongs to the high overall technological gap category. The probable reason for this outcome might be the low level of adoption of recommendations and medium level of socio-economic status.

The above findings are in congruence with the findings of Patel and Vyas (2014), who found that 65.00 per cent of sugarcane growers had medium technological gap, followed by low (19.00 per cent) and high (16.00 per cent) technological gap in adoption of improved sugarcane cultivation practices, respectively.
Technological gap with respect to recommended individual paddy cultivation practices

The data with respect to the technological gap for different practices of paddy cultivation is presented in table 2 , reveals that 75.00 per cent technological gap was reported by respondent paddy growers in the recommended practice "Herbicide in transplanted field", this outcome may be attributed to use of other herbicides as observed during the filed visits by the researcher.71.00 percent gap was observed in practicing Split application of nitrogen fertilizer, it may be due to lack of knowledge leading to lower level of adoption. There was 69.00 percent technological gap in use of recommended herbicide in nursery, it was observed that very few farmers raised seedlings in nursery, most of them purchased seedlings for transplantation, this might have led to poor knowledge and adoption.

In case of adoption of recommended level of water at tillering stage the gap was 66.00 percent, it might be due to lack of knowledge and also the availability of irrigation at that time, as it was noticed and expressed by farmers too, farmers at the tail end of the irrigation canal face shortage of water during such crucial time. 61.00 percent gap was found in case of adoption of green manuring crops and also size of seed bed, it may be due to availability and use of chemical fertilizers very few farmers adopted the technology and, as said above very few farmers had nursery so they possessed limited knowledge of all the practices of nursery management. Following practices reported technological gap ranging between 50.00 percent to less than 60.00 percent, "Level of water before harvesting (59.00\% gap)", "Pesticide for bacterial blight (58.00 \% gap)", "Time of transplanting (57.00 \% gap)", "Number of cartload of FYM (57.00 \% gap)", "Number of seedlings per hill (55.00 
\% gap)", "Time of sowing seed in seed bed (54.00 \% gap)", "Dosage of NPK/ha $(51.00 \%$ gap)", these above outcomes might be due to lack of through knowledge or having partial knowledge leading to medium level of adoption.

Table.1 Distribution of the respondents according to their overall technological gap

\begin{tabular}{|c|c|c|c|c|}
\hline Sr. & Category & Frequency & Percentage & Mean score \\
\hline 1. & Low (Up to 33.99) & 15 & 15.00 & 21.94 \\
\hline 2. & Medium (Between 34 to 84.99 & 85 & 85.00 & 56.51 \\
\hline 3. & High (More than 85.00) & 0 & 0.00 & 00.00 \\
\hline & Total & 100 & 100.00 & - \\
\hline
\end{tabular}

$($ Mean $=51.33)($ Standard deviation $=16.96)$

Table.2 Distribution of respondents according to technological gap with respect to recommended individual paddy cultivation practices $(\mathrm{n}=100)$

\begin{tabular}{|l|c|}
\hline \multicolumn{1}{|c|}{ Recommended package of practices } & Gap in percentage \\
\hline 1. Recommended Green manure crop & 61.00 \\
\hline 2. Recommended level of water at puddling & 49.00 \\
\hline 3. Recommended variety & 24.00 \\
\hline 4. Recommended area of nursery for one hectare & 47.00 \\
\hline 5. Recommended size of seed bed & 61.00 \\
\hline 6. Recommended time of seed sowing in seed bed & 54.00 \\
\hline 7. Recommended seed rate & 43.00 \\
\hline 8. Recommended chemical for seed treatment & 71.00 \\
\hline 9. recommended age of seedling to be used & 42.00 \\
\hline 10. Recommended time of transplanting & 57.00 \\
\hline 11. Recommended spacing in main field & 36.00 \\
\hline 12. Recommended number of seedlings per hill & 55.00 \\
\hline 13. Recommended number of cartloads of FYM /ha & 57.00 \\
\hline 14. Recommended dosage of NPK & 51.00 \\
\hline 15. Recommended split application of nitrogen & 70.00 \\
\hline 16. Recommended level of water at tillering stage & 66.00 \\
\hline 17. Recommended level of water before harvesting & 59.00 \\
\hline 18. Recommended herbicide in nursery & 69.00 \\
\hline 19. Recommended herbicide in transplanted field & 75.00 \\
\hline 20. Recommended pesticide for BPH & 29.00 \\
\hline 21. Recommended pesticide for rice gundhi bug & 32.00 \\
\hline 22. Recommended pesticide for Bacteria blight & 58.00 \\
\hline 23. Recommended pesticide for rice blast & 37.00 \\
\hline 24. Recommended stage of crop for harvesting & 29.00 \\
\hline
\end{tabular}


Table.3 Relationship between the overall technological gap and selected independent variables

\begin{tabular}{|c|l|l|}
\hline Sr. & \multicolumn{1}{|c|}{ Independent Variables } & Coefficient of Correlation (' $\mathbf{r}^{\text {' Value) }}$ \\
\hline 1. & Age & $+0.253^{*}$ \\
\hline 2. & Education & $-0.217^{*}$ \\
\hline 3. & Farming experience & $+0.195^{\mathrm{NS}}$ \\
\hline 4. & Land holding & $+0.190^{\mathrm{NS}}$ \\
\hline 5. & Annual income & $-0.207^{*}$ \\
\hline 6. & Material possession & $+0.011^{\mathrm{NS}}$ \\
\hline 7. & Extension contact & $-0.201^{*}$ \\
\hline 8. & Mass media exposure & $-0.239^{*}$ \\
\hline 9. & Extension participation & $-0.198^{*}$ \\
\hline 10. & Risk orientation & $-0.262^{*}$ \\
\hline 11. & Scientific orientation & $-0.273^{*}$ \\
\hline 12. & Social participation & $-0.221^{*}$ \\
\hline$*$ significant at $0.05, * *$ significant at 0.01, NS $=$ Non Significant \\
\hline
\end{tabular}

Less than 50.00 percent technological gap was found in following practices; "Level of water during puddling (49.00\% gap)", "Area of nursery for one hectare (47.00\% gap)", “ Seed rate (43.00\% gap)", "Age of seedling to be used (42.00\% gap)", "Pesticide for rice blast (37.00\% gap)", "Spacing in main field (36.00\% gap)", "Pesticide for rice gundhi bug (32.00 \% gap)", "Pesticide for BPH (29.00\% gap)", "Stage of crop for harvesting (29.00\% gap)" and "Variety (24.00\% gap), these findings might have been factored by high level of knowledge among respondents, availability of the technology, its ease of use and affordability, relative advantage and some are no-cost technologies, thus lower gaps are seen.

\section{Relationship between the overall technological gap and selected independent variables}

From the data presented in the table 3 , it is evident that independent variable "Risk orientation" and "Scientific orientation" were negatively and significantly associated with the overall technological gap at one per cent level of significance, risk bearing ability is one of the prime attributes of an entrepreneur, thus farmers with higher risk bearing ability are ready to adopt the said technology, thus lower will be the technological gap. As the etymological meaning of science is "to know", farmers with scientific orientation are eager to know the new which might have factored in adoption of technologies and thus low level of gap. Socio economic variables such as "Education", "Annual income", education and income are crucial for knowledge, affordability and adoption of any proven technology, thus have nullify the gaps, thus they were reported to be negatively and significantly associated with overall technological gap at five percent level of significance. Other socio-economic variables such as "Mass media exposure", "Extension participation", "Extension contact" and "Social participation" were negatively and significantly associated with overall technological gap at five per cent level of significance, these exposures will enhance farmers' knowledge and adoption, this might 
be the probable reason for the reported outcome. This indicated that technological gap is dependent on the above discussed independent variables, as the aforementioned independent variables pose their effect on overall technological gap.

Further, age of the respondent paddy growers was positively and significantly associated with overall technological gap at five per cent level of significance. Independent variables such as "Farming experience", "Land holding", "Material possession" were positively and non-significantly associated with overall technological gap. The current findings of the study are medium level of profile of the respondents, medium level of technological gap, and the negative and significant association of technological gap and selected variables. In order to narrow down the technological gap, the adoption of those least adopted technologies need to be increased. The negatively associated variable have to be strengthen so that adoption is increased and gap is narrowed.

\section{References}

Anonymous. 2014a. Annual report 20132014. Department of Agriculture and Cooperation, Government of India.p.25.

Anonymous. 2014b. Annual Progress Report 2013-14. Krishi Vigyan Kendra, Navsari. p.9 10.

Anonymous. 2014c. Annual Progress Report 2013-14. Krishi Vigyan Kendra, Surat. p.9.

Food and Agriculture Organization. 2014. Rice market monitor, report 17(1): 1-5.
Food and Agriculture Organization. 2015. Rice market monitor, report 18(2): 2-6.

Mehta, Atul, M., Pathak, A. R., Prajapati, K. S., Makwana, M. G, Bhuva, N. P., Patel, S. G., Saiyad M R, Patel, K H, Chauhan, C. B, Bhalani G. K, Dodiya J F, Patel R C, Chauhan N P, Patel, V. J., Desai, M. U. and Patel, B. J. 2010. "Rice Research at a Glance." MRRS Technical Bulletin No. 1/2010, Main Rice Research Station, AAU, Nawagam- 387540, Ta \& Dist: Kheda. pp. 35.

Narendra, S., Dikshit, A. K., Reddy, B. S. and Surendra, B. K. 2014. Instability in Rice Production in Gujarat: A Decomposition Analysis. Asian Journal of Economics and Empirical Research, 1(1): 6- 9 .

Patel, A. G and Vyas H U. 2014 . Technological Gap in Adoption of Sugarcane Cultivation Practices by Sugarcane Growers. Gujarat Journal of Extension Education, 25: 227-229.

Rogers Everett M and Floyd F. Shoemaker (1971). Communication of Innovations: A Cross-Cultural Approach. New York, Free Press. C (£).

Sharma, J. K. 2012. Technological gap in major cropping patterns of small farms under medium land conditions in Nalbari District of Assam. Journal of Academic and Industrial Research, 1(7): 388-392.

Singh, D. P. and Yadav, S. K. 2014. Knowledge and Adoption gap of Tribal farmers of Bastar towards Rice Production Technology. AIJRHASS. 5456.

\section{How to cite this article:}

Tengli, M.B. and Sharma, O.P. 2017. Technological Gap in Adoption of Improved Paddy Cultivation Practices. Int.J.Curr.Microbiol.App.Sci. 6(11): 1224-1229. doi: https://doi.org/10.20546/ijcmas.2017.611.145 